\title{
Study on the indexes of basic sanitation and human development in the state of Minas Gerais, Brazil: a panorama in the context of the new sanitation framework
}

In 2020, the sanitation framework was updated by the Brazilian Federal Law $n=14,026 / 2020$ to advance the sanitation sector throughout the country. This study aims to evaluate and correlate the indices related to basic sanitation with indexes of economic and social development of the municipalities of the state of Minas Gerais, Brazil. The consultation and collection of data on the treatment and distribution of drinking water were carried out from the government databases. They were correlated with the various human and sanitation indicators to perform the present work. It was obtained that the mean and standard deviation of the data of the index of attendance with Wastewater Treatment Plant (WWTPs) evaluated (2013-2035) are, respectively, 92.02\% and 0.13\%. It was possible to conclude that there is a tendency to increase the percentage values of the population with piped water with the quality-of-life indices of the population.

Keywords: Basic sanitation; Legal framework; Universalization.

\section{Estudo sobre os índices de saneamento básico e desenvolvimento humano no estado de Minas Gerais, Brasil: um panorama no contexto do novo quadro de saneamento}

\begin{abstract}
Em 2020, o quadro de saneamento foi atualizado pela Lei Federal Brasileira no 14.026/2020 para avançar o setor de saneamento em todo o país. Este estudo tem como objetivo avaliar e correlacionar os índices relacionados ao saneamento básico com os índices de desenvolvimento econômico e social dos municípios do estado de Minas Gerais, Brasil. A consulta e coleta de dados sobre tratamento e distribuição de água potável foram realizadas a partir dos bancos de dados governamentais. Eles foram correlacionados com os diversos indicadores humanos e de saneamento para a realização do presente trabalho. Obteve-se que a média e o desvio padrão dos dados do índice de atendimento com Estação de Tratamento de Efluentes (ETEs) avaliados (2013-2035) são, respectivamente, 92,02\% e $0,13 \%$. Foi possível concluir que há uma tendência de aumento dos valores percentuais da população com água encanada com os índices de qualidade de vida da população.
\end{abstract}

Palavras-chave: Saneamento básico; Enquadramento jurídico; Universalização.

Topic: Engenharia Sanitária

Reviewed anonymously in the process of blind peer.
Received: 03/07/2021

Approved: 28/07/2021
Alana Lopes Junho

Universidade Federal de Itajubá, Brasil

http://lattes.cnpq.br/4076970255485963

alana.junho@outlook.com

Regina Mambeli Barros

Universidade Federal de Itajubá, Brasil

http://lattes.cnpq.br/9289407545513503

http://orcid.org/0000-0003-3154-2956

mambeli@unifei.edu.br

Ivan Felipe Silva dos Santos

Universidade Federal de Itajubá, Brasil

http://lattes.cnpq.br/1175675008975515

ivanfelipedeice@hotmail.com
Geraldo Lucio Tiago Filho (iD

Universidade Federal de Itajubá, Brasil

http://lattes.cnpq.br/1838249887289555

http://orcid.org/0000-0002-2755-4316

tiago unifei@hotmail.com
Referencing this:

JUNHO, A. L.; BARROS, R. M.; SANTOS, I. F. S.; TIAGO FILHO, G. L. Study on the indexes of basic sanitation and human development in the state of Minas Gerais, Brazil: a panorama in the context of the new sanitation framework. Revista Ibero Americana de Ciências Ambientais, v.12, n.7, p.195-210, 2021. DOI:

http://doi.org/10.6008/CBPC2179-6858.2021.007.0019 


\section{INTRODUCTION}

Although it is recognized as a fundamental human right, universal access to basic sanitation still faces many challenges globally, including in Brazil (CUNHA et al., 2018). According to Dantas et al. (2012), Brazil faces a significant challenge concerning basic sanitation, especially about sewage collection and treatment. According to the authors, although the investments provided by the Growth Acceleration Program (PAC, in Portuguese) were intended to improve all sanitation in Brazil, there was a concern of municipalities in ensuring access to drinking water. Consequently, sewage treatment did not receive a precise dimension of the investments to be made.

According to the Brazilian National Sanitation Information System (BRAZIL, 2019), in its last Diagnosis of Water and Sewage Services - 2018, launched in December 2019, 83.6\% of the population is served by a water supply network, and only $53.2 \%$ is served by sewage collection. Concerning the sewage generated that is treated, only $46.3 \%$ of the population is served with this service. In this scenario, more than $50 \%$ of the sewage generated in Brazil is released in nature into the water bodies (BRASIL, 2019).

The National Basic Sanitation Survey (PNSB, in Portuguese) was published by the Brazilian Institute of Geography and Statistics (IBGE, in Portuguese) in 2020 and addressed the rates of drinking water supply and sewage through the survey conducted in the 1989/2017 period. According to PNSB, there was an advance in drinking water supply rates in Brazilian municipalities, while the care related to sanitary sewage remains below expected. The proportion of municipalities with sewage services increased from $47.3 \%$ in 1989 to $60.3 \%$ in 2017. The water supply service increased from $95.9 \%$ in 1989 to $99.6 \%$ in 2017 (IBGE, 2020).

Minas Gerais is a Brazilian state with a population of $18,886,672$ inhabitants. It is the state with the largest number of municipalities in the country, with 853 according to the most recent census conducted by IBGE in 2010 (IBGE, 2020). According to Minas Gerais (2020), this state has a high urban population served by sewage collection, of approximately $16,216,463$ inhabitants, which corresponds to $85.86 \%$ of the population of Minas Gerais. However, the same is not the case in the sewage treatment scenario, where only $49.45 \%$ (about 9,339,577 inhabitants) of the urban population is served.

In Brazil, the competent legislation in sanitation had as its initial milestone in the 1970s. The National Sanitation Plan (PLANASA, in Portuguese) and the Sanitation Financial System (SFS, in Portuguese) were created. Both policies were managed at this time by the National Housing Bank (BNH, in Portuguese), with resources from the Service Time Guarantee Fund (FGTS), and intended to provide sanitation services to sanitation companies since they had access to BHN loans (NOZAKI, 2007).

Since the creation of the Ministry of Cities, Brazil has resumed investments and restructured the country's sanitation area. However, it was only in 2007 the legal framework for the definition and implementation of basic sanitation services in the country, with the enactment of Law $\mathrm{N}^{\circ} .11,445$ of January 5, 2007, called the "Basic Sanitation Law", establishing national guidelines for the provision and management of services (BRAZIL, 2007).

To ensure the availability of quality water to present and future generations, Law $N^{\circ}$. 9,433 (Water 
Study on the indexes of basic sanitation and human development in the state of Minas Gerais, Brazil: a panorama in the context of the new

Law) (BRAZIL, 1997) was approved on January 8, 1997, establishing the National Water Resources Policy and creating the National Water Resources Management System (SINGREH, in Portuguese).

Internationally, the United Nations (UN) proposed a new sustainable development agenda in 2015 to its member countries for the next 15 years, the 2030 Agenda, composed of the 17 Sustainable Development Goals (SDGs). Among these SDGs, SDG 6 is defined as "Ensuring the availability and sustainable management of water and sanitation for all".

The update of the Legal Framework of Basic Sanitation was sanctioned on July 15, 2020, by Federal Law $N^{\circ} .14026 / 2020$, aiming at the universalization of basic sanitation in Brazil (BRASIL, 2020). In addition, this law aimed to enabling and ensuring the universalization of services until $12 / 31 / 2033$, serving $99 \%$ of the population with drinking water and $90 \%$ with sewage collection and treatment (BRAZIL, 2020).

Some authors analyzed the relation between society's quality of life and basic sanitation. For example, to investigate the effect of dependence on natural resources on access to water and sanitation, Tadadjeu et al. (2020) and Ndikumana et al. (2017) used an empirical model based on the dynamic framework. The authors used two versions of a baseline model. The first version of the model, used by Ndikumana et al. (2017), related the total income from natural resources to the percentage of the population (total, rural and urban, alternatively) with access to improved water sources or sanitation facilities. The second version used by Tadadjeu et al. (2020), who carried out a study with 44 countries in Africa from 1995 to 2017, seeks to study the effect of total incomes from natural resources on the urban-rural gap in access to water and sanitation, respectively.

Tadadjeu et al. (2020) concluded by analyzing the baseline models that there is a negative relationship between total incomes from natural resources and access to water and sanitation, both for the entire population and for urban and rural areas. Although theoretically, natural resource rents provide governments with a continuous source of income necessary for investments in the provision of social services such as electricity, water, sanitation, education and health care.

Ndikumana et al. (2017) investigated whether targeting external aid to the water and sanitation sector can help achieve the goal of expanding access to water and sanitation services in Africa through data estimation. The authors suggest that the increase in aid directed to water supply and sanitation is associated with increased access to these services, although the relationship is not linear.

\section{METHODOLOGY}

We have performed the consultation and collection of data on the treatment and distribution of drinking water in a government database to perform the present work, such as: The Brazilian National Water Agency (Agência Nacional das Águas, ANA) - The Sewer Atlas (ANA, 2020); Atlas of Human Development of Municipalities of UNDP/Brazil (UNDP/Atlas) (BRAZIL, 2020); The Brazilian Institute of Geography and Statistics (IBGE).

In this study, the various human and sanitation indicators were correlated to verify Brazil's basic 
sanitation framework. We used the Microsoft ${ }^{\circledast}$ Excel $^{\circledR}$ tools to correlate data in a linear function. For simple statistical analysis, we used the free software Paleontological Statistics Software Package for Education and Data Analysis - PAST4.03 (HAMMER, 2001).

Then, the cities from Minas Gerais were subdivided into classes. The study was carried out on the variables investments in collection and treatment of sewage per capita $\left(R \$ / h^{2} b_{2035}\right)$ versus the population served estimated in 2035 versus the index of care with WWTPs evaluated (2013-2035) (C): up to 5,000 inhabitants; from 5001 to 10000 inhabitants; from 10001 to 20000 inhabitants; from 20001 to 50000 inhabitants; from 50001 to 100000 inhabitants; from 100001 to 500000 inhabitants; and more than 500 000 inhabitants.

\section{RESULTS AND DISCUSSION}

Figure 1 shows the correlation between the percentage parameters of the population with piped water versus life expectancy at birth.

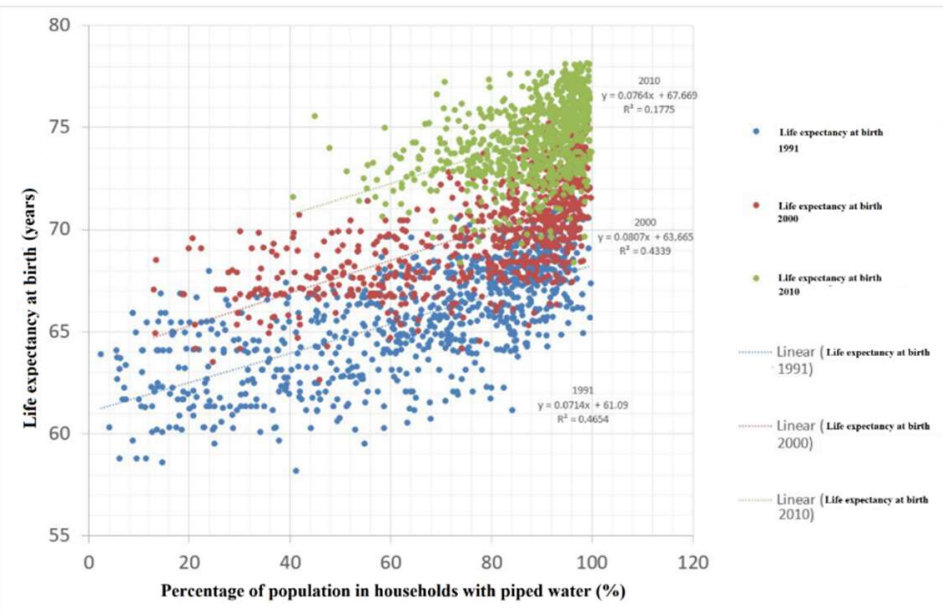

Figure 1: Percentage of the population with piped water versus life expectancy at birth.

The values obtained from the statistical analysis of the variables presented in Figure 1 using the software PAST ${ }^{\oplus}$ are described in Table 1.

Table 1: Results of statistical analysis among the percentage variables of the population with piped water Versus life expectancy at birth in 1991, 2000 and 2010.

\begin{tabular}{|c|c|c|c|}
\hline \multicolumn{4}{|c|}{ Results of statistical analysis } \\
\hline \multicolumn{4}{|l|}{1991} \\
\hline \multicolumn{4}{|c|}{ Ordinary least squares regression: $A^{*}-B^{* *}$} \\
\hline Slope to: & 0,071421 & Standard error to: & 0,0026256 \\
\hline $\mathrm{T}:$ & 27,202 & $\mathrm{p}$ (slope): & $1,0410^{-117}$ \\
\hline Intercept b: & 61,09 & Standard error b: & 0,18272 \\
\hline \multicolumn{4}{|c|}{ 95\% initialized confidence intervals ( $\mathrm{N}=1999)$ : } \\
\hline Slope to: & \multicolumn{3}{|l|}{$(0,06603,0,076749)$} \\
\hline Intercept b: & \multicolumn{3}{|l|}{$(60,705,61,473)$} \\
\hline \multirow{2}{*}{\multicolumn{4}{|c|}{$\begin{array}{l}\text { correlation: } \\
\mathrm{R}:\end{array}$}} \\
\hline & & & \\
\hline r2: & \multicolumn{3}{|l|}{0,46539} \\
\hline $\mathrm{T}:$ & \multicolumn{3}{|l|}{27,202} \\
\hline $\mathrm{p}$ (uncorr.): & \multicolumn{3}{|l|}{$1,0410^{-117}$} \\
\hline Permutation $\mathrm{p:}$ & \multicolumn{3}{|l|}{0,0001} \\
\hline
\end{tabular}


Study on the indexes of basic sanitation and human development in the state of Minas Gerais, Brazil: a panorama in the context of the new

\begin{tabular}{|c|c|c|c|}
\hline \multicolumn{4}{|l|}{2000} \\
\hline \multicolumn{4}{|c|}{ Ordinary least squares regression: $A^{*}-B^{* *}$} \\
\hline Slope to: & 0,080692 & Standard error to: & 0,0031616 \\
\hline $\mathrm{T}:$ & 25,523 & $\mathrm{p}$ (slope): & $4,0710^{-107}$ \\
\hline Intercept b: & 63,665 & Standard error b: & 0,26194 \\
\hline \multicolumn{4}{|c|}{ 95\% initialized confidence intervals ( $N=1999)$ : } \\
\hline Slope to: & \multicolumn{3}{|l|}{$(0,074244,0,086825)$} \\
\hline Intercept b: & \multicolumn{3}{|l|}{$(63.146 ; 64.194)$} \\
\hline \multirow{2}{*}{\multicolumn{4}{|c|}{$\begin{array}{l}\text { correlation: } \\
\text { R: }\end{array}$}} \\
\hline & & & \\
\hline r2: & \multicolumn{3}{|l|}{0.43386} \\
\hline $\mathrm{T}:$ & \multicolumn{3}{|l|}{25.523} \\
\hline p (uncorr.): & \multicolumn{3}{|l|}{$4.07 \cdot 10^{-107}$} \\
\hline Permutation $\mathrm{p:}$ & \multicolumn{3}{|l|}{0.0001} \\
\hline \multicolumn{4}{|l|}{2010} \\
\hline \multicolumn{4}{|c|}{ Ordinary least squares regression: $A^{*}-B^{* *}$} \\
\hline Slope to: & 0.076441 & Standard error to: & 0.0056431 \\
\hline $\mathrm{T}:$ & 13.546 & $\mathrm{p}$ (slope): & $5.40 \cdot 10^{-38}$ \\
\hline Intercept b: & 67.669 & Standard error b: & 0.50191 \\
\hline \multicolumn{4}{|c|}{ 95\% initialized confidence intervals ( $\mathrm{N}=1999)$ : } \\
\hline Slope to: & \multicolumn{3}{|l|}{$(0.064808 ; 0.086913)$} \\
\hline Intercept b: & \multicolumn{3}{|l|}{$(66.738 ; 68.725)$} \\
\hline \multicolumn{4}{|l|}{ correlation: } \\
\hline R: & \multicolumn{3}{|l|}{0.42136} \\
\hline r2: & \multicolumn{3}{|l|}{0.17755} \\
\hline $\mathrm{T}:$ & \multicolumn{3}{|l|}{13.546} \\
\hline $\mathrm{p}$ (uncorr.): & \multicolumn{3}{|l|}{$5.40 .10^{-38}$} \\
\hline Permutation $\mathrm{p}$ : & \multicolumn{3}{|l|}{0.0001} \\
\hline \multicolumn{4}{|c|}{${ }^{*}$ A: Percentage of the population with piped water } \\
\hline \multicolumn{4}{|c|}{$* *$ B: life expectancy at birth } \\
\hline
\end{tabular}

In the graph of Figure 1, which addresses the percentage of the population with piped water versus life expectancy at birth, there is a tendency to increase the percentage values of the population with piped water and life expectancy at birth regarding the years 1991, 2000, and 2010. The obtained linear correlation coefficients between the variables for the years 1991, 2000, and 2010 resulted in low values, respectively, of $0.4654,0.4339$, and 0.1775 due to data dispersion. Moreover, it is noted that when compared to 1991,2010 presents higher rates of care of the population in households treated with piped water and higher life expectancy at the population's birth, evidencing the proportionality of the indexes. It is observed that over the years 1991, 2000, and 2010 the improvement in the rates of service with piped water supply caused higher rates of life expectancy at birth, with the years 1991 and 2010 being the lowest and the highest rate of care, respectively.

As shown in Table 1, the linear correlation values $\left(R^{2}\right)$ resulted from 1991, 2000, and 2010, respectively, of $0.46539,0.43386$, and 0.17755 . These values are very close to those obtained in the analysis of Figure 1. Table 2 shows the values obtained in Pearson's linear correlation test, performed in the software PAST $^{\circledR}$. In bold, the r-Pearson values corresponding to the percentage of the population and life expectancy at the birth of the respective year are highlighted.

Table 2: Linear test results $r$ - Pearson.

\begin{tabular}{|l|l|l|l|l|l|l|}
\hline & $\mathrm{A}^{1}$ & $\mathrm{~B}^{2}$ & $\mathrm{C}^{3}$ & $\mathrm{D}^{4}$ & $\mathrm{E}^{5}$ & $\mathrm{~F}^{6}$ \\
\hline $\mathrm{A}^{1}$ & & $3.745 .10^{-320}$ & $1.63 .10^{-83}$ & $\mathbf{1 . 0 4 . 1 0 ^ { - 1 1 7 }}$ & $5.82 .10^{-130}$ & $5.73 .10^{-113}$ \\
\hline $\mathrm{B}^{2}$ & 0.90629 & & $1.24 .10^{-108}$ & $1.83 .10^{-93}$ & $\mathbf{4 . 0 7 . 1 0 ^ { - 1 0 7 }}$ & $1.43 .10^{-90}$ \\
\hline $\mathrm{C}^{3}$ & 0.59732 & 0.66218 & & $1.13 .10^{-33}$ & $1.22 .10^{-37}$ & $\mathbf{5 . 4 0 . 1 0 ^ { - 3 8 }}$ \\
\hline
\end{tabular}


Study on the indexes of basic sanitation and human development in the state of Minas Gerais, Brazil: a panorama in the context of the new

JUNHO, A. L.; BARROS, R. M.; SANTOS, I. F. S.; TIAGO FILHO, G. L.

\begin{tabular}{|l|l|l|l|l|l|l|}
\hline $\mathrm{D}^{4}$ & $\mathbf{0 . 6 8 2 1 9}$ & 0.62488 & 0.39772 & & $2.39 .10^{-277}$ & $3.96 .10^{-119}$ \\
\hline $\mathrm{E}^{5}$ & 0.70689 & $\mathbf{0 . 6 5 8 6 8}$ & 0.4195 & 0.8802 & & $5.11 .10^{-166}$ \\
\hline $\mathrm{F}^{6}$ & 0.67194 & 0.61714 & $\mathbf{0 . 4 2 1 3 6}$ & 0.68519 & 0.76707 & \\
\hline${ }^{1} \mathrm{~A}:$ percentage of the population with piped water 1991; \\
${ }^{2} \mathrm{~B}:$ percentage of the population with piped water 2000; \\
${ }^{3} \mathrm{C}:$ percentage of the population with piped water 2010; \\
${ }^{4} \mathrm{D}:$ life expectancy at birth 1991; \\
${ }^{5} \mathrm{E}:$ life expectancy at birth 2000; and \\
${ }^{6} \mathrm{~F}:$ life expectancy at birth 2010.
\end{tabular}

Figure 2 shows the relationship between the percentage of the population with piped water Versus MHDI - Longevity dimension. The values obtained from the statistical analysis among the variables mentioned above are presented in Table 3.

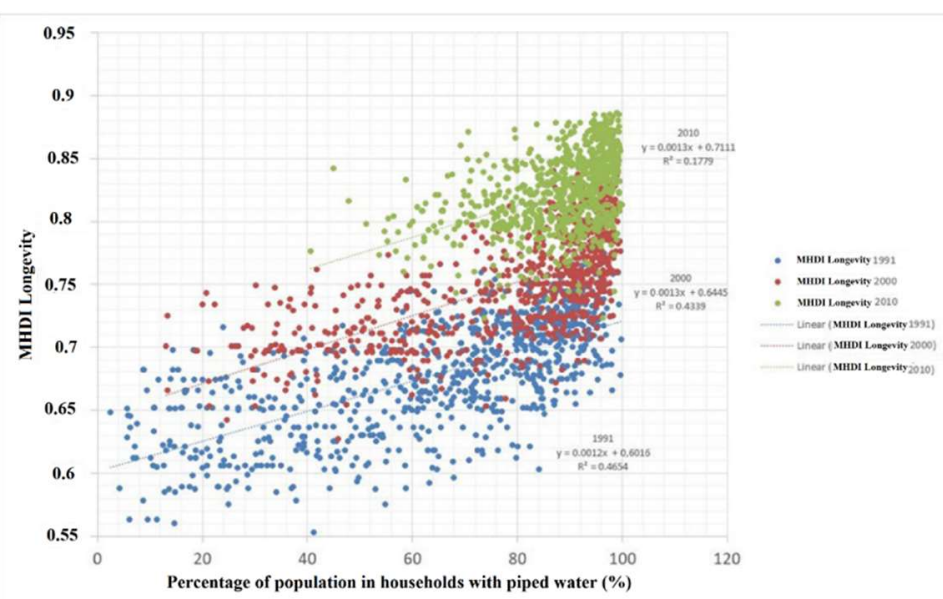

Figure 2: Percentage of the population with piped water versus MHDI - Longevity Dimension.

Table 3: Results of statistical analysis among variables percentage of the population with piped water Versus HDI-M Longevity Dimension in 1991, 2000 and 2010.

\begin{tabular}{|c|c|c|c|}
\hline \multicolumn{4}{|c|}{ Results of statistical analysis } \\
\hline \multicolumn{4}{|l|}{1991} \\
\hline \multicolumn{4}{|c|}{ Ordinary least squares regression: $A-B$} \\
\hline Slope to: & 0.00119 & Standard error to: & $4.37 .10^{-05}$ \\
\hline $\mathrm{T}:$ & 27.201 & $\mathrm{p}$ (slope): & $1.06 .10^{-117}$ \\
\hline Intercept b: & 0.60164 & Standard error b: & 0.0030438 \\
\hline \multicolumn{4}{|c|}{ 95\% initialized confidence intervals ( $N=1999)$ : } \\
\hline Slope to: & \multicolumn{3}{|c|}{$(0.0011005 ; 0.0012824)$} \\
\hline Intercept b: & \multicolumn{3}{|c|}{$(0.59487 ; 0.608)$} \\
\hline correlation: & \multirow{2}{*}{\multicolumn{3}{|c|}{0.68218}} \\
\hline $\mathrm{R}:$ & & & \\
\hline r2: & \multicolumn{3}{|l|}{0.46537} \\
\hline $\mathrm{T:}$ & \multicolumn{3}{|l|}{27.201} \\
\hline $\mathrm{p}$ (uncorr.): & \multicolumn{3}{|l|}{$1.06 \cdot 10^{-117}$} \\
\hline Permutation $\mathrm{p}$ : & \multicolumn{3}{|l|}{0.0001} \\
\hline \multicolumn{4}{|l|}{2000} \\
\hline \multicolumn{4}{|c|}{ Ordinary least squares regression: $A-B$} \\
\hline Slope to: & 0.080692 & Standard error to: & 0.0031616 \\
\hline $\mathrm{T:}$ & 25.523 & p (slope): & $4.07 .10^{-107}$ \\
\hline Intercept b: & 63.665 & Standard error b: & 0.26194 \\
\hline \multicolumn{4}{|c|}{ 95\% initialized confidence intervals ( $N=1999)$ : } \\
\hline Slope to: & \multicolumn{3}{|c|}{$(0.074508 ; 0.086729)$} \\
\hline Intercept b: & \multicolumn{3}{|c|}{$(63.171 ; 64.174)$} \\
\hline correlation: & \multirow{2}{*}{\multicolumn{3}{|c|}{0.65868}} \\
\hline R: & & & \\
\hline r2: & \multicolumn{3}{|l|}{0.43386} \\
\hline $\mathrm{T:}$ & \multicolumn{3}{|l|}{25.523} \\
\hline $\mathrm{p}$ (uncorr.): & \multicolumn{3}{|l|}{$4.07 \cdot 10^{-107}$} \\
\hline
\end{tabular}


Study on the indexes of basic sanitation and human development in the state of Minas Gerais, Brazil: a panorama in the context of the new

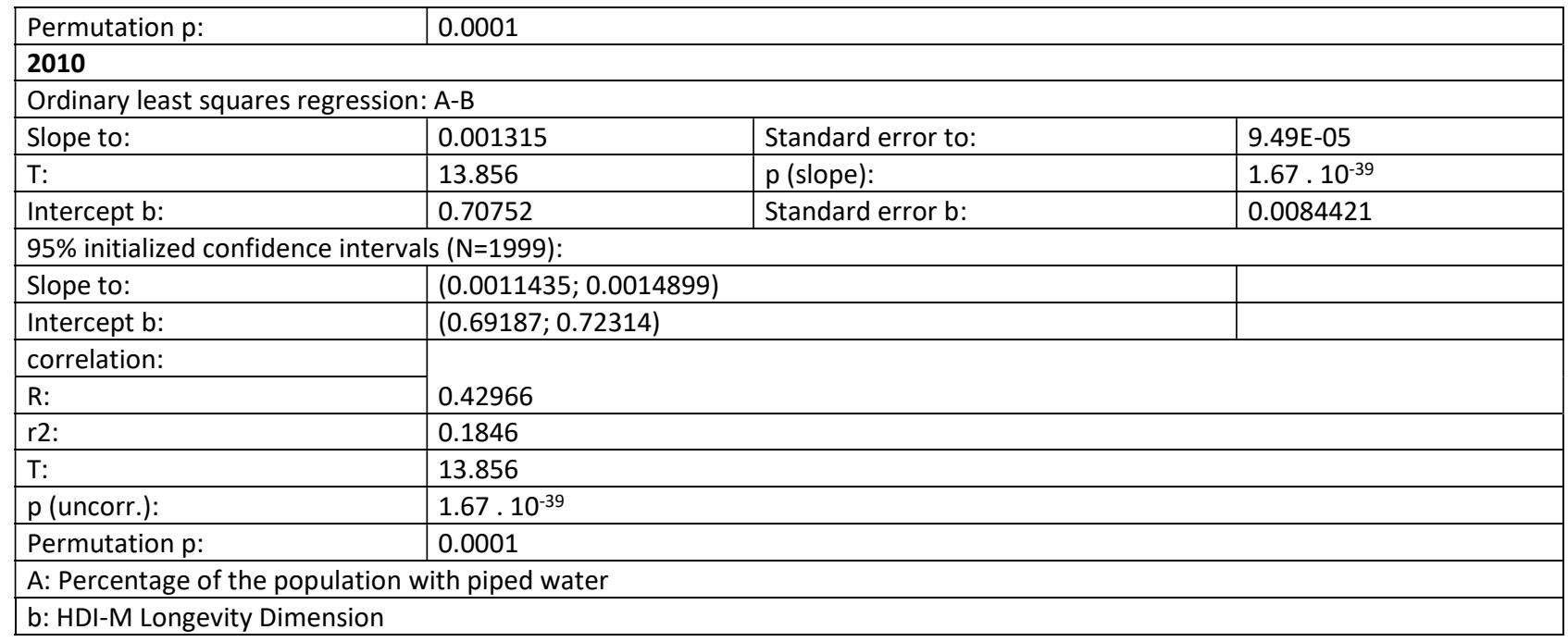

From the analysis of the values in Table 2, it can be observed that the values from the relationship between the percentage of the variable of the population with piped water and life expectancy at birth have a moderate positive association. These values are $0.68219,0.65868$, and 0.42136 for the years 1991,2000 , and 2010. Despite this relationship, it cannot be concluded that changes in one variable cause changes in another variable based only on correlation. When changing the position variables, leaving on the $x$-axis the life expectancy data at birth and on the $y$ axis the percentage of the population with piped water, the respective values are already very low (1,04.10-117, 4.07.10-107, and 5.40.10-38).

The graph from Figure 2 on the percentage of the population with piped water versus MHDI Longevity Dimension presents the same trend as the graph in Figure 1. There is a tendency to increase the percentage values of the population with piped water and also the MHDI - Longevity Dimension, from the years 1991 to the year 2000 and 2010. It can be affirmed, despite the linear correlation coefficients, $r^{2}$, between the variables for the years 1991,2000 , and 2010, of $0.4654,0.4339$, and 0.1779 , respectively. It is observed that over the years 1991, 2000, and 2010 the improvement in the rates of service with piped water supply caused higher values for the MHDI - Longevity Dimension. In addition, it is observed that over the years, the rates of piped water care have improved and concentrated on better rates. Values from Table 3 present the linear correlation coefficients $\left(R^{2}\right)$ between the variables for the years 1991, 2000, and 2010. They were close to the values of the correlations obtained by the Microsoft ${ }^{\circledast}$ Excel $^{\circledast} 0.4654 ; 0.4339$ and 0.1846. Table 4 presents the values obtained in the r-Pearson linear correlation test. In bold, the r-Pearson values corresponding to the percentage of the population with piped water and $\mathrm{MHDI}$ of the respective years are highlighted.

Table 4: Linear Test Results $r$ - Pearson.

\begin{tabular}{|l|l|l|l|l|l|l|}
\hline & $\mathrm{A}^{1}$ & $\mathrm{~B}^{2}$ & $\mathrm{C}^{3}$ & $\mathrm{D}^{4}$ & $\mathrm{E}^{5}$ & $\mathrm{~F}^{6}$ \\
\hline $\mathrm{A}^{1}$ & & $3.5117 .10^{-319}$ & $6.31 \mathrm{E}-87$ & $\mathbf{2 . 3 9 . 1 0 ^ { - 1 1 7 }}$ & $5.63 .10^{-130}$ & $9.44 .10^{-113}$ \\
\hline $\mathrm{B}^{2}$ & 0.90617 & & $2.00 .10^{-113}$ & $3.03 .10^{-93}$ & $\mathbf{4 . 3 5 . 1 0 ^ { - 1 0 7 }}$ & $1.76 .10^{-90}$ \\
\hline $\mathrm{C}^{3}$ & 0.60764 & 0.67353 & & $1.20 .10^{-34}$ & $3.24 .10^{-38}$ & $\mathbf{1 . 6 7 . 1 0 ^ { - 3 9 }}$ \\
\hline $\mathrm{D}^{4}$ & $\mathbf{0 . 6 8 2 0 1}$ & 0.62487 & 0.40364 & & $6.82 .10^{-277}$ & $4.74 .10^{-119}$ \\
\hline $\mathrm{E}^{5}$ & 0.70749 & $\mathbf{0 . 6 5 9 1 9}$ & 0.42298 & 0.88033 & & $2.84 .10^{-166}$ \\
\hline $\mathrm{F}^{6}$ & 0.67204 & 0.61746 & $\mathbf{0 . 4 2 9 6 6}$ & 0.6856 & 0.768 & \\
\hline
\end{tabular}




\begin{tabular}{|l|l|l|l|l|}
\hline & $\mathrm{A}^{1}$ & $\mathrm{~B}^{2}$ & $\mathrm{D}^{4}$ & $\mathrm{E}^{5}$ \\
\hline${ }^{2} \mathrm{~B}:$ percentage of the population with piped water 2000; & & \\
3C: percentage of the population with piped water 2010; & & \\
${ }^{3} \mathrm{D}:$ HDI-M Longevity Dimension 1991; & & \\
${ }^{5} \mathrm{E}:$ HDI-M Longevity Dimension 2000; and & & \\
${ }^{6} \mathrm{~F}:$ HDI-M Longevity Dimension 2010.
\end{tabular}

Figure 3 shows the bubble chart relationship between the percentage of the variable of the population with piped water, life expectancy at birth, and MHDI Dimension Longevity for the years 1991 (Figure 3a), 2000 (Figure 3b), and 2010 (Figure 3c).

(a)

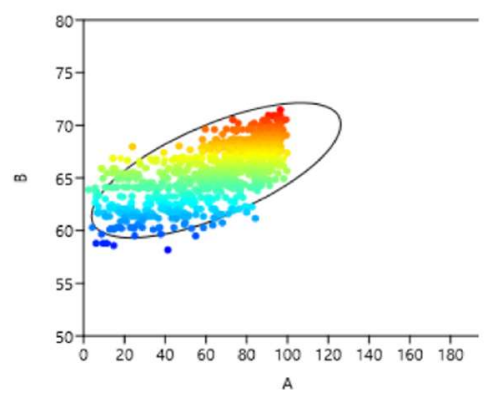

(b)

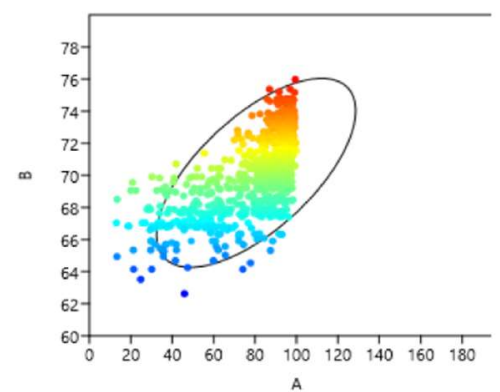

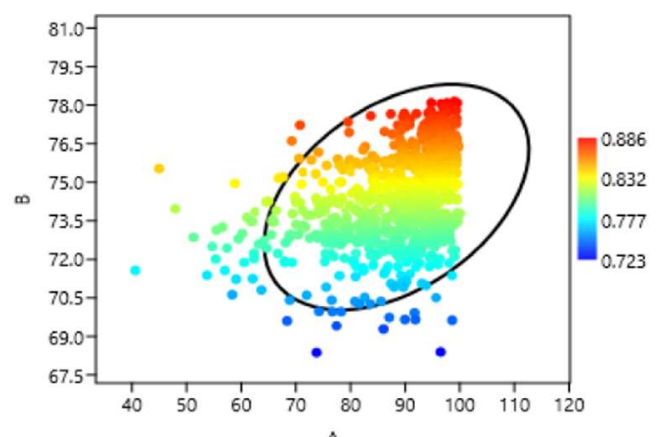

(c)

Figure 3: Bubble chart ratio between the variables (A) percentage of the population with piped water, (B) life expectancy at birth and MHDI Longevity Dimension for the years: a) 1991 (upper right), 2000 (upper left) and 2010 (lower).

Figure 4 shows the linear correlation between an increase in the index of WWTPs evaluated (20132035) versus the amount to be achieved by investments in sewage collection and treatment per capita for an estimated population in the state of Minas Gerais in 2035 ( $R \$ / h^{2} b_{2035}$ ). In other words, this variable estimates how much should be invested (in reais, $\mathrm{R} \$$ ) for each inhabitant in 2035 , aiming at the universalization of access to the collection and treatment of sanitary sewage in Minas Gerais.

From the values presented in Table 4, it can be observed that the relationship between the percentage of the variable of the population with piped water and HDI-M Longevity Dimension have a moderate positive relationship, respectively $0.68201 ; 0.65919$ and 0.42966 for the years 1991,2000 , and 2010. Despite this relationship, it cannot be concluded that changes in one variable cause changes in another variable based only on correlation. When changing the position variables, leaving on the $x$-axis the MHDI values and the $y$-axis the percentage of the population with piped water, the respective values are very low $\left(2,39.10^{-117}, 4,35.10^{-107}\right.$, and $\left.1,67.10^{-39}\right)$. 


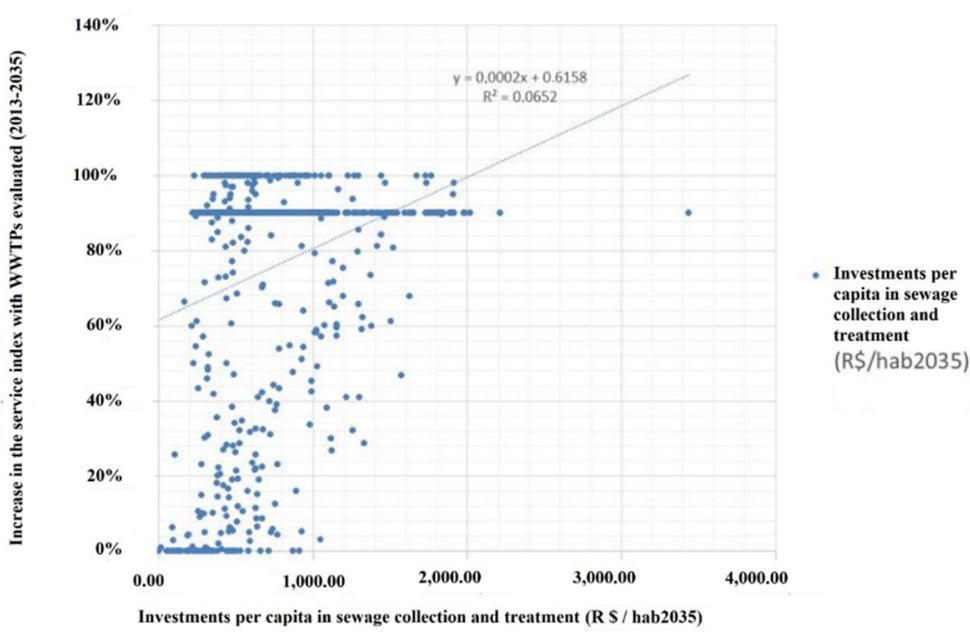

Figure 4: Linear correlation between the variables investments in collection and treatment per capita (R\$/hab2035) versus increase in the index of WWTPs scare rate evaluated (2013-2035).

The graph in Figure 3 shows data within the ellipse that represent $95 \%$ of the data and the ratio of the population to piped water (A) versus life expectancy at birth (B) versus MHDI Longevity Dimension. It is verified that there is a tendency to increase the percentage values of the population with piped water, life expectancy at birth, and MHDI Longevity Dimension for the years 1991, 2000 and finally, 2010. The higher the percentages of the piped water population, the higher the values of life expectancy at birth and the higher the HDI-M Longevity Dimension, respectively.

The graph analysis in Figure 4 shows a low linear correlation coefficient between the variables investments in per capita sewage collection and treatment (R\$/hab2035) versus an increase in the index of care with evaluated WWTPs (2013-2035), whose value is 0.0652 .

Figure 5 shows the bubble chart between variables population served estimated in 2035 (obtained through the database) (A), index of care with ETEs evaluated (2013-2035) (B) versus investments in sewage collection and treatment per capita (R\$/hab2035) (C).

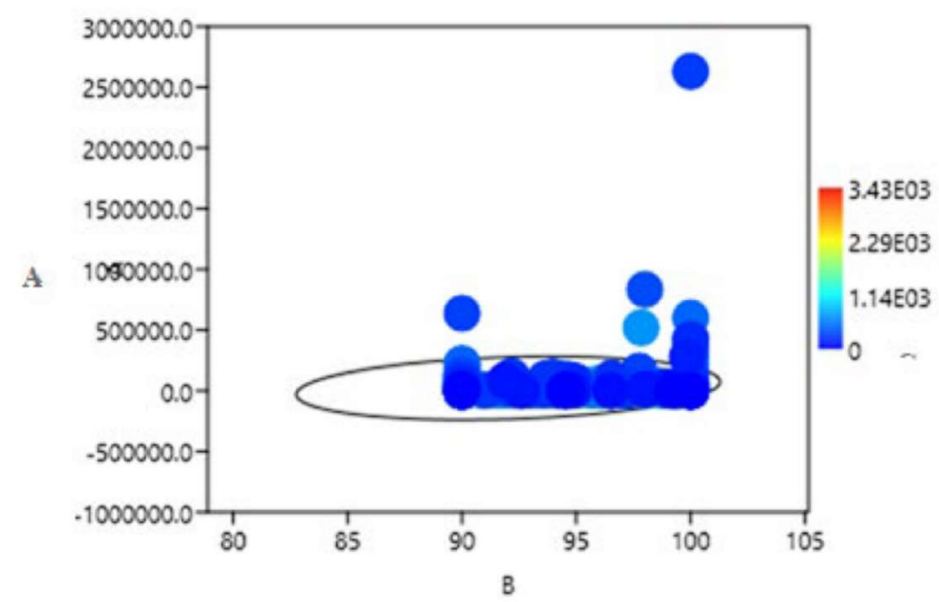

Figure 5: Bubble graph among variables population served estimated in 2035 (A), investments in sewage collection and treatment per capita (R\$/hab2035) (B) Versus index of service with WWTPs evaluated (2013-2035) (C).

Table 5 presents the statistical results among the variables population served estimated in 2035 (obtained through the database) (A), index of care with ETEs evaluated (2013-2035) (B) and investments in collection and treatment of sewage per capita (R\$/hab2035) (C). Table 6 shows the results of the linear test 
$r$ - Pearson for the same variables presented in Figure 5.

Table 5: Statistical results.

\begin{tabular}{|l|l|l|l|}
\hline & A & B & C \\
\hline $\mathbf{N}$ & 853 & 853 & 853 \\
\hline Min & 482 & 90 & 0 \\
\hline max & 2631460 & 100 & 3432,86 \\
\hline sum & $1.95 .10^{+07}$ & 78493.5 & 588910.1 \\
\hline average & 22880.23 & 92.02051 & 690.3987 \\
\hline Standard error & 3646.323 & 0.1294338 & 14.55429 \\
\hline variance & $1.13 .10^{+10}$ & 14.29039 & 180688.7 \\
\hline Deviation - Standard & 106495.1 & 3.780264 & 425.075 \\
\hline Media & 5702 & 90 & 573.04 \\
\hline 25th percentile & 3017 & 90 & 407.005 \\
\hline 75th percentile & 13721 & 90 & 852.6 \\
\hline Skewness & 18.59526 & 1.468896 & 1.514007 \\
\hline Kurtosis & 430.1626 & 0.3193424 & 2.918655 \\
\hline Geometric mean & 91.94589 & 0 \\
\hline Mr. Coef. Var & 7232.667 & 6.108066 & 61.56949 \\
\hline A: Population Served Estimated in 2035 & \\
\hline B: Index of Service with ETEs Evaluated (2035) & \\
\hline C: Investments in Collection and Treatment per capita (R\$/hab 2035$)$ & \\
\hline
\end{tabular}

Table 6: Linear Test Results $r$ - Pearson.

\begin{tabular}{|l|l|l|l|}
\cline { 2 - 4 } \multicolumn{1}{c|}{} & A & B & C \\
\hline A & & $3.40 .10^{-09}$ & 0.0029076 \\
\hline B & 0.20063 & & $2.30 .10^{-05}$ \\
\hline C & -0.10183 & -0.1444 & \\
\hline A: Population Served Estimated in 2035 & \\
\hline \multicolumn{2}{|l|}{ B: Index of Service with ETEs Evaluated (2035) } \\
\hline \multicolumn{2}{|l}{ C: Investments in Collection and Treatment per capita (R\$/hab2035) } \\
\hline
\end{tabular}

In the graph presented in Figure 5, the values within the ellipse represent $95 \%$ of the data, mainly constituting small cities in which investments in sewage collection and treatment do not generally exceed the value of about $1,140.00 \mathrm{R} \$ /$ hab2035.

By analyzing the data in Table 5, it is verified that in 2035 the population will be more than 19 million, and the average rate of service with WWTPs in 2035 will be $92 \%$, while the maximum investment value is R\$ $3,432.86$ per inhabitant. These values, concerning the collection and treatment of sanitary sewage, are in agreement with Art. 11-B of Law N $N^{\circ}$. 14026/2020 (BRASIL, 2020), of the legal framework of sanitation. It is defined as a goal of universalizing the following values: $99 \%$ of the population with drinking water and $90 \%$ of the population with sewage collection and treatment by December 31, 2033. However, the planning of the goals described for 2035 should be adapted to the law mentioned above for 2033 .

By analyzing the data in Table 6, it is verified that the data Population Serviced Estimated in 2035 versus Index of Service with WWTPs Evaluated (2035) and Population Attended Estimated in 2035 versus Investments in Collection and Treatment per capita (R\$/hab2035) are directly proportional. On the other hand, analyzing the Index of Service with WWTPs Evaluated (2035) versus Investments in Collection and Treatment per capita (R\$/hab2035) is inversely proportional. In other words, the higher the rates of care with WWTPs, the lower the investments in collection and per capita treatment required. As for the results of the linear test $r$ - Pearson, very low values are observed for all combinations between the variables as mentioned 
above. We analyzed various indicators of quality of human life with the subdivision into classes of municipalities by the size of the population. Figure 6 presents the correlations for the MHDI are analyzed versus population classes for the years 1991, 2000, and 2010, respectively.

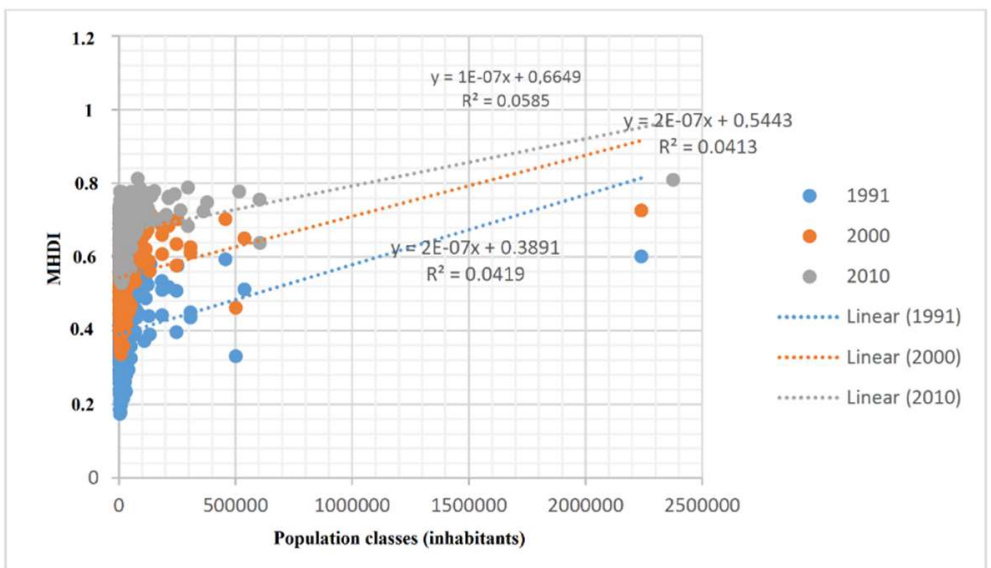

Figure 6: MHDI versus population classes.

Table 7 shows the r-Pearson values for the data presented in Figure 6 . In bold the r-Pearson values corresponding to the population and the MHDI of the respective years are highlighted.

Table 7: R-Pearson values for the population and $\mathrm{MHDI}$ relationship.

\begin{tabular}{|c|c|c|c|c|c|c|}
\hline & $A^{1}$ & $B^{2}$ & $C^{3}$ & $D^{4}$ & $E^{5}$ & $\mathrm{~F}^{6}$ \\
\hline$A^{1}$ & & 0.000523 & $1.1510^{-195}$ & $2.17 .10^{-09}$ & $6.66 .10^{-190}$ & $5.82 .10^{-11}$ \\
\hline$B^{2}$ & 0.11873 & & $3.86 .10^{-07}$ & $3.14 .10^{-07}$ & $1.35 .10^{-07}$ & $5.19 .10^{-12}$ \\
\hline $\mathrm{C}^{3}$ & 0.80641 & 0.17294 & & 0.001921 & 0 & $1.88 .10^{-10}$ \\
\hline $\mathrm{D}^{4}$ & 0.20353 & 0.17425 & 0.10626 & & \begin{tabular}{|l|l|}
0.00075 \\
\end{tabular} & $6.33 .10^{-15}$ \\
\hline$E^{5}$ & 0.79949 & 0.17953 & 0.99914 & 0.1154 & & $3.99 .10^{-11}$ \\
\hline$F^{6}$ & 0.22225 & 0.2336 & 0.21626 & 0.26295 & 0.22398 & \\
\hline $\begin{array}{l}{ }^{1} \mathrm{~A}: \\
{ }^{2} \mathrm{~B}: \\
{ }^{3} \mathrm{C}: \\
{ }^{4} \mathrm{D}: \\
{ }^{5} \mathrm{E}: \\
{ }^{6} \mathrm{~F}:\end{array}$ & $\begin{array}{l}\text { ulation } 10 \\
\text { DI } 1991 \\
\text { ulation } 20 \\
\text { IDI } 2000 \\
\text { ulation } 20 \\
\text { DI } 2010\end{array}$ & & & & & \\
\hline
\end{tabular}

Figure 6 shows low values for linear correlation $\left(R^{2}\right)$ equal to $0.0585 ; 0.0413$ and 0.0419 . In other words, there is a low linear correlation between the analyzed parameters. It appears that the MHDI was high during the analyzed scenarios, with the classes of smaller cities having the highest concentrations of the lowest $\mathrm{MHDI}$; in addition, it appears that the largest cities have higher MHDI.

The r-Pearson values are presented in Table 7. There is a positive relationship between population and the respective MHDI variables, respectively $0.000523,0.001921$, and $3.99 .10^{-11}$, for 1991 , 2000, and 2010. Despite this relationship, it cannot be concluded that changes in one variable cause changes in another variable based only on correlation. When changing the position variables, leaving on the $\mathrm{x}$-axis the MHDI values and on the $y$-axis the population class, the respective values also result in low $(0,11873,0.10626$, and $0.22398)$.

By correlating life expectancy data at birth versus population classes, we obtained the graph shown in Figure 7. Table 8 shows the r-Pearson values for the data presented in Figure 7. In bold the r-Pearson 
values corresponding to the population and life expectancy at birth of the respective years are highlighted.

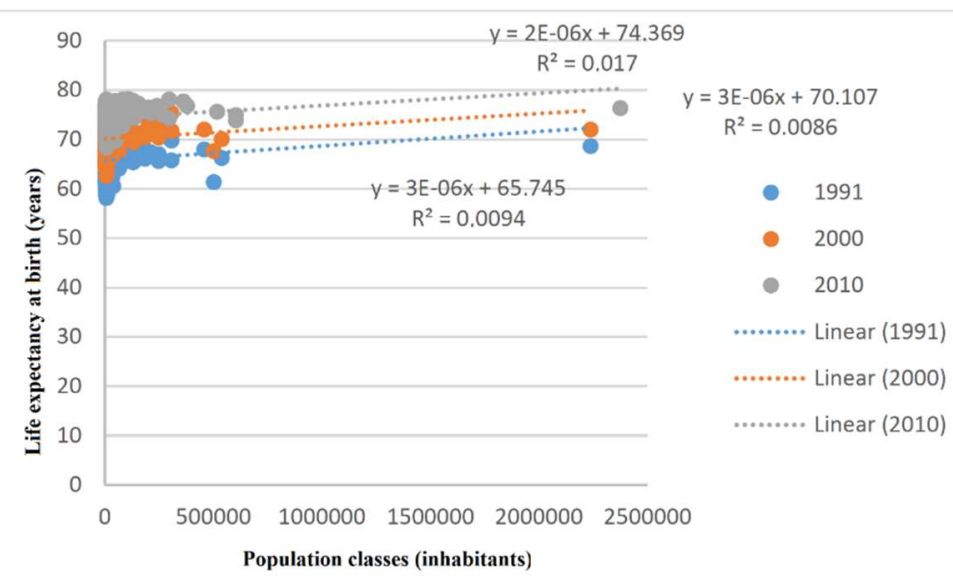

Figure 7: Life expectancy at birth versus population classes.

Table 8: R-Pearson values for the population versus life expectancy at the birth relationship.

\begin{tabular}{|c|c|c|c|c|c|c|}
\hline & $A^{1}$ & $B^{2}$ & $\mathrm{C}^{3}$ & $\mathrm{D}^{4}$ & $E^{5}$ & $\mathrm{~F}^{6}$ \\
\hline$A^{1}$ & & 0.004914 & 3.96.10-196 & 0.025518 & $2.34 .10^{-190}$ & 0.007259 \\
\hline $\mathrm{B}^{2}$ & 0.096276 & & $3.71 .10^{-05}$ & 0.001738 & $4.15 .10^{-05}$ & $3.87 .10^{-05}$ \\
\hline$C^{3}$ & 0.80642 & 0.14082 & & 0.006892 & 0 & 0.000236 \\
\hline $\mathrm{D}^{4}$ & 0.076562 & 0.1072 & 0.092508 & & 0.005291 & $9.56 .10^{-05}$ \\
\hline$E^{5}$ & 0.7995 & 0.13994 & 0.99914 & 0.095462 & & 0.000136 \\
\hline $\mathrm{F}^{6}$ & 0.091971 & 0.14057 & 0.12565 & 0.13334 & 0.13036 & \\
\hline $\begin{array}{l}{ }^{1} \mathrm{~A}: \\
{ }^{2} \mathrm{~B}: \\
{ }^{3} \mathrm{C}: \\
{ }^{4} \mathrm{D}: \\
{ }^{5} \mathrm{E}: \\
{ }^{6} \mathrm{~F}:\end{array}$ & $\begin{array}{l}\text { oulation } 19 \\
\text { expectanc } \\
\text { ulation } 20 \\
\text { expectanc } \\
\text { ulation } 20 \\
\text { expectanc }\end{array}$ & $\begin{array}{l}1991 \\
2000 \\
2010\end{array}$ & & & & \\
\hline
\end{tabular}

By correlating the percentage of hospitalizations for diseases related to inadequate environmental sanitation versus population classes, the graph shown in Figure 8 was obtained.

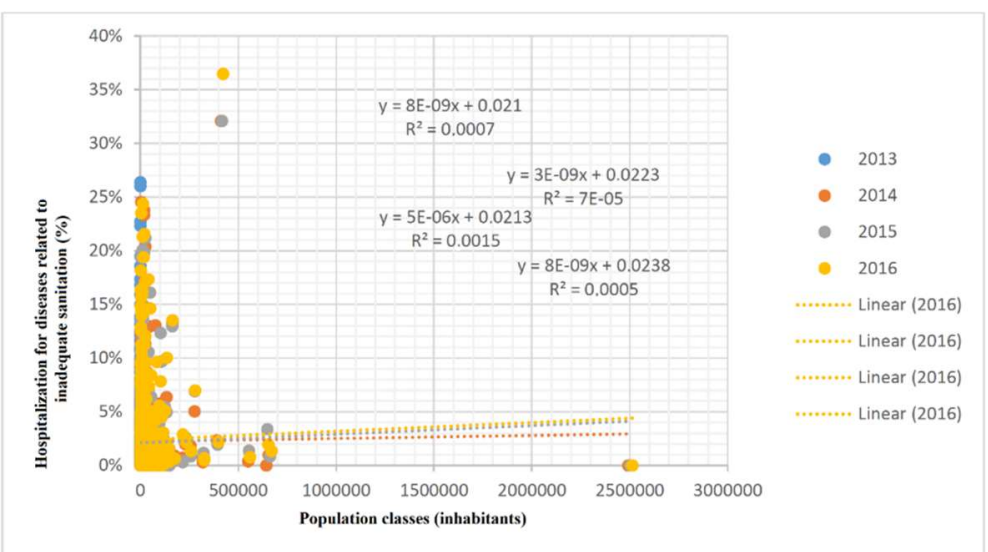

Figure 8: Percentage of hospitalizations for diseases related to inadequate environmental sanitation versus population classes.

Table 9 presents the analysis of r-Pearson values of the data shown in Figure 8, in bold. The r-Pearson values corresponding to the population and the percentage of hospitalizations for diseases related to inadequate environmental sanitation of the respective years are highlighted in bold. 
Study on the indexes of basic sanitation and human development in the state of Minas Gerais, Brazil: a panorama in the context of the new

Table 9: R-Pearson values for the relationship between population versus percentage hospitalizations for diseases related to inadequate environmental sanitation.

\begin{tabular}{|c|c|c|c|c|c|c|c|c|}
\hline & $A^{1}$ & $\mathrm{~B}^{2}$ & $\mathrm{C}^{3}$ & $\mathrm{D}^{4}$ & $E^{5}$ & $\mathrm{~F}^{6}$ & $\mathrm{G}^{7}$ & $\mathrm{H}^{8}$ \\
\hline$A^{1}$ & & 0.61199 & 0 & 0.80871 & 0 & 0.4588 & 0 & 0.51293 \\
\hline$B^{2}$ & 0.017402 & & 0.60697 & $2.05 .10^{-21}$ & 0.60222 & $6.26 .10^{-11}$ & 0.59764 & $1.86 .10^{-05}$ \\
\hline $\mathrm{C}^{3}$ & 1 & 0.017648 & & 0.80284 & 0 & 0.4533 & 0 & 0.50694 \\
\hline $\mathrm{D}^{4}$ & 0.008306 & 0.31738 & 0.008566 & & 0.79676 & $1.04 .10^{-17}$ & 0.79209 & $3.22 .10^{-08}$ \\
\hline $\mathrm{E}^{5}$ & 0.99999 & \begin{tabular}{|l|}
0.017881 \\
\end{tabular} & 1 & 0.008836 & & 0.44811 & 0 & 0.50121 \\
\hline $\mathrm{F}^{6}$ & 0.025413 & 0.22138 & 0.025726 & 0.28728 & 0.026022 & & 0.44357 & $8.07 .10^{-29}$ \\
\hline $\mathrm{G}^{7}$ & 0.99997 & 0.018107 & 0.99999 & 0.009044 & 1 & 0.026283 & & 0.49618 \\
\hline $\mathrm{H}^{8}$ & 0.022445 & 0.146 & 0.022765 & 0.18769 & 0.023073 & 0.36804 & 0.023345 & \\
\hline \multicolumn{9}{|c|}{${ }^{1} \mathrm{~A}:$ Total population 2013} \\
\hline \multicolumn{9}{|c|}{${ }^{2} \mathrm{~B}: \%$ of hospitalizations for diseases related to inadequate environmental sanitation 2013} \\
\hline \multicolumn{9}{|c|}{${ }^{3} \mathrm{C}$ : Total population 2014} \\
\hline \multicolumn{9}{|c|}{${ }^{4} \mathrm{D}: \%$ of hospitalizations for diseases related to inadequate environmental sanitation 2014} \\
\hline \multicolumn{9}{|c|}{${ }^{5} \mathrm{E}:$ Total population 2015} \\
\hline \multicolumn{9}{|c|}{${ }^{6} \mathrm{~F}: \%$ of hospitalizations for diseases related to inadequate environmental sanitation 2015} \\
\hline \multicolumn{9}{|c|}{${ }^{7} \mathrm{G}$ : Total population 2016} \\
\hline \multicolumn{9}{|c|}{${ }^{8} \mathrm{H}: \%$ of hospitalizations for diseases related to inadequate environmental sanitation 2016} \\
\hline
\end{tabular}

Low linear correlation values were obtained through the analysis of Figure 7 , being equal to 0.017 , 0.0094 , and 0.008 , i.e., there is no linear correlation between the evaluated parameters. However, it is verified that life expectancy at birth increased over the years, indicating better conditions and quality of life of the population and led to higher life expectancy rates at birth.

Table 8 shows the $r$-Pearson analysis. It is verified that the relationship between the variables is positive, being equal to $0.004914,0.006892$, and 0.000136 for the years 1991,2000 , and 2010 respectively. When the axes are reversed, the coefficients equal to 0.096276 are obtained; 0.092508 and 0.1306 for 1991 , 2000 and 2010, remaining a positive relationship between the variables.

Figure 8 shows low linear correlation values, equal to $0.007,0,0015,0.0005$, and $7.10^{-05}$, indicating no linear correlation between the variables. However, it is verified that the most populated cities have the lowest percentages of hospitalization, while the less populated cities are the most heterogeneous, with higher and lower hospitalization rates.

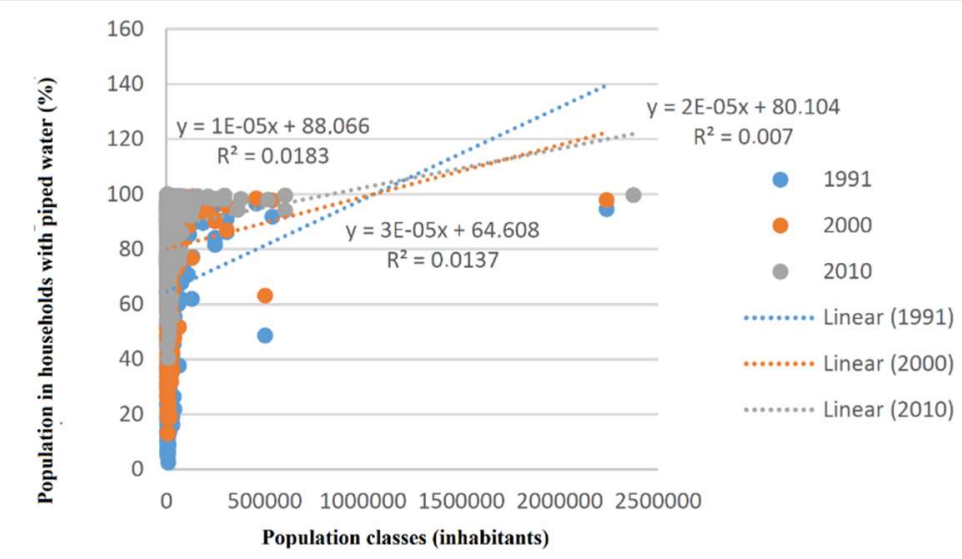

Figure 9: Percentage of population with piped water versus population classes.

As shown in Table 9, when performing the analysis of $r$-Pearson values, it is verified that these are positive relationships and analyzed population versus percentage of hospitalizations for diseases related to inadequate environmental sanitation and the inverse of the relationship. When studying the correlation 
between the percentage of the population in households with running water versus the population classes, we obtained the graph as shown in Figure 9.

From the analysis of the graph of Figure 9, there are low values of linear correlation $\left(R^{2}\right)$, being equal to $0.007,0.0183$, and 0.0137 , indicating that there is a very low linear correlation between the analyzed parameters. However, it is verified that the most populated mining cities have higher percentages of care for the years 1991, 2000, and 2010, respectively. Moreover, it is evident that over the time analyzed (1991 to 2010), there is an increase in the rate of the population that has piped water in less populated cities. Moreover, the lowest population rates with piped water are found in less populated cities.

Table 10 shows the $r$-Pearson values for the percentage of the population with running water versus classes of population in bold. The r-Pearson values corresponding to the relationship for the respective years are highlighted.

Table 10: R-Pearson values for the population versus population relationship percentage of the population with piped water.

\begin{tabular}{|c|c|c|c|c|c|c|}
\hline & $A^{1}$ & $\mathrm{~B}^{2}$ & $C^{3}$ & $\mathrm{D}^{4}$ & $E^{5}$ & $F^{6}$ \\
\hline$A^{1}$ & & 0.000446 & $6.76 .10^{-196}$ & 0.018618 & $3.67 .10^{-213}$ & 0.000688 \\
\hline $\mathrm{B}^{2}$ & 0.12011 & & $1.03 .10^{-07}$ & 0.018357 & $2.33 .10^{-08}$ & 0.042357 \\
\hline$C^{3}$ & 0.80641 & 0.1812 & & 0.014834 & $2.34 .10^{-190}$ & 0.000136 \\
\hline $\mathrm{D}^{4}$ & 0.08065 & 0.080829 & \begin{tabular}{|l|}
0.083447 \\
\end{tabular} & & 0.000329 & 0.06094 \\
\hline$E^{5}$ & 0.82556 & 0.19 & 0.7995 & 0.12276 & & $2.69 .10^{-09}$ \\
\hline$F^{6}$ & 0.1162 & 0.069646 & 0.13042 & 0.064266 & 0.20214 & \\
\hline \multicolumn{7}{|c|}{$\begin{array}{l}{ }^{1} \mathrm{~A}: \text { Population in } 1991 \\
{ }^{2} \mathrm{~B}: \% \text { population with piped water } 1991 \\
{ }^{3} \mathrm{C} \text { : Population in } 2000 \\
{ }^{4} \mathrm{D}: \% \text { population with piped water } 2000 \\
{ }^{5} \mathrm{E}: \text { Population in } 2010 \\
6 \mathrm{~F}: \% \text { population with piped water } 2010\end{array}$} \\
\hline
\end{tabular}

As shown in Table 10 by the analysis of $r$-Pearson values, it is verified that the population relationship versus percentage of the population in households with piped water values equal to $0.000446 ; 0.014834$, and $2.69 .10^{-09}$. Although they are relatively low values, this is a positive relationship between the parameters. The same also occurs when reversing the axes, obtaining values equal to $0.12011,0.083447$, and 0.20214 .

\section{CONCLUSIONS}

The present study aimed to evaluate and correlate data from drinking water supply statistically and sewage collection and treatment, with quality of life indexes of the population of the state of Minas Gerais aiming at universalization to basic sanitation services, having as background Law N ${ }^{\circ}$. 14026/2020 (BRASIL, 2020), sanctioned in the country.

It is verified through the data obtained that there is a tendency to increase the percentage values of the population with piped water and also the life expectancy at birth of the years 1991, 2000, and 2010. These numbers also indicated that there was an improvement in the rate of care over time $t$.

There is also a trend of increasing percentage values of the population with piped water Versus MHDI - Longevity dimension, concerning the years 1991, 2000, and 2010. It was observed that over the observed periods, there was an increase in the rates of care and MHDI. It is noted that higher rates of care with water 
Study on the indexes of basic sanitation and human development in the state of Minas Gerais, Brazil: a panorama in the context of the new sanitation framework

JUNHO, A. L.; BARROS, R. M.; SANTOS, I. F. S.; TIAGO FILHO, G. L.

supply to the population provide better indicators of quality of life of the population, such as higher rates of life expectancy at birth and MHDI.

The analyses showed a low coefficient of linear correlation between the investments in sewage collection and treatment per capita (R\$/hab2035) variables versus an increase in the index of WWTPs evaluated (2013-2035).

In the joint analysis between variables investments in sewage collection and treatment per capita ( $R$ \$ / hab2035) versus the population served estimated in 2035 versus the rate of service with evaluated WWTPs (2013-2035), it appears that most cities (95\% within the ellipse) are small cities. Therefore, investments in sewage collection and treatment do not generally exceed the value of about $1,140.00$ R\$/hab2035 (average of 690.40 R\$/hab2035 with a standard deviation of 425.08 R\$/ hab2035).

The amounts to be achieved by investments in sewage collection and treatment per capita ( $R \$$ /hab2035) seek universal access to sewage collection and treatment in Minas Gerais, from 90-100\% of the population to be served (average of $92.02 \%$ and standard deviation of $0.13 \%$ ). Concerning the collection and treatment of sanitary sewage, these values are in line with Art. 11-B of Law N. 14026/2020 (BRAZIL, 2020), of the legal framework of sanitation (universalization goals that guarantee the attendance of $90 \%$ of the population with sewage collection and treatment until December 31, 2033). However, the planning of the goals that have been described for 2035 must conform to the aforementioned law, for 2033.

ACKNOWLEDGMENTS: The authors would like to thank the Brazilian National Council for Scientific and Technological Development (Conselho Nacional de Desenvolvimento Científico e Tecnológico, CNPq; in Portuguese) for granting the Productivity in Research scholarship to Prof. Regina Mambeli Barros (PQ2, Process number: 303805/2018-0), to Prof. Geraldo Lúcio Tiago Filho.

\section{REFERENCES}

BRAZIL. Ministry of Cities. National Sanitation Secretariat SNS. National Sanitation Information System: 24th Diagnosis of Water and Sewage Services: 2018. Brasilia: SNS/MDR, 2019.

BRAZIL. Law N. 11,445 of 5 January 2007. Establishes national guidelines for basic sanitation; amends the laws in us. 6,766, of December 19, 1979, 8,036, of May 11, 1990, 8,666 of June $21,1993,8,987$ of February 13, 1995; repeals Law No. 6,528 of May 11, 1978; and makes other arrangements. Brasilia: Presidency of the Republic, 2007.

BRAZIL. Law N. 14,026 of July 15, 2020. Updates the legal framework for basic sanitation and amends Law No. 9,984 of July 17, 2000, to assign the National Agency for Water and Basic Sanitation (ANA) the power to edit reference standards on sanitation service, Law No. 10,768, of November 19, 2003 , to change the name and attributions of the position of Specialist in Water Resources, Law No. 11,107, of April 6, 2005 , to prohibit the provision by contract of the program of the public services dealt with article 175 of the Federal Constitution, Law No. 11,445, of January 5, 2007, to improve the structural conditions of basic sanitation in the country,
Law No. 12,305 of August 2, 2010, to address the deadlines for the environmentally appropriate final disposal of the tailings, Law No. 13,089 of January 12, 2015 (Statute of the Metropolis), to extend its scope to microregions, and Law No. 13,529 of December 4, 2017, to authorize the Union to participate in the fund for the exclusive purpose of financing specialized technical services. Brasilia: Official Federal Gazette, 2020.

BRAZIL. Law N. 9,433 of January 8, 1997. It establishes the National Water Resources Policy, creates the National Water Resources Management System, regulates the XIX item of Art. 21 of the Federal Constitution, and amends Article 1 of Law No. 8,001 of March 13, 1990, which modified Law No. 7,990 of December 28, 1989. Brasília: Official Federal Gazette, 1997.

CUNHA, M. A.; BORJA, P. C.. The program of accelerating growth in the state of Bahia and the challenges of universalization of basic sanitation. Urbe. Revista Brasileira de Gestão Urbana, v.10, n.1, p.173-185, 2018. DOI: http://dx.doi.org/10.1590/2175-3369.010.supl1.ao09 
DANTAS, F. V. A.; LEONETI, A. B.; OLIVEIRA, S. V. W. B.; OLIVEIRA, M. M. B.. An analysis of the sanitation situation in Brazil. Facef Pesquisa: Desenvolvimento e Gestão, v.15, n.3, p.272-284, 2012.

HAMMER, O.; HARPER, D. A. T.; RYAN, P. D.. PAST: Paleontological Statistics Software Package for Education and Data Analysis. Version 4.03. Palaeontological Association, 2001.

IBGE. The Brazilian Institute of Geography and Statistics. National Basic Sanitation Survey 2017: water supply and sanitation. Rio de Janeiro: IBGE, 2020.

MINAS GERAIS. Secretary of State for Environment and Sustainable Development. Panorama of sanitary sewage in Minas Gerais: preliminary report. Secretary of State for Environment and Sustainable Development. Belo Horizonte:
Semad, 2020.

NDIKUMANA, L.; PICKBOURN, L.. The Impact of Foreign Aid Allocation on Access to Social Services in sub-Saharan Africa: The Case of Water and Sanitation. World Development, v.90, p.104-114, 2017. DOI:

http://doi.org/10.1016/j.worlddev.2016.09.001

NOZAKI, V. T.. Analysis of the basic sanitation sector in Brazil. Thesis (Master in Applied Economics) - University of São Paulo, Ribeirão Preto, 2007.

TADADJEU, S.; NJANGANG, H.; NINGAYE, P.; NOUROU, M. Linking natural resource dependence and access to water and sanitation in African countries. Resources Policy, v.69, n.101880, 2020.

http://doi.org/10.1016/i.resourpol.2020.101880

A CBPC - Companhia Brasileira de Produção Científica (CNPJ: 11.221.422/0001-03) detém os direitos materiais desta publicação. Os direitos referem-se à publicação do trabalho em qualquer parte do mundo, incluindo os direitos às renovações, expansões e disseminações da contribuição, bem como outros direitos subsidiários. Todos os trabalhos publicados eletronicamente poderão posteriormente ser publicados em coletâneas impressas sob coordenação da Sustenere Publishing, da Companhia Brasileira de Produção Científica e seus parceiros autorizados. Os (as) autores (as) preservam os direitos autorais, mas não têm permissão para a publicação da contribuição em outro meio, impresso ou digital, em português ou em tradução. 